\title{
Does Diversification and Executive Compensation Affect Corporate Values in Family Firm: Case of Indonesia
}

\section{Habiburrochman, Wahyu Inayatul Fadilah, and Siti Zulaikha}

Fakultas Ekonomi dan Bisnis-Universitas Airlangga

\section{Abstract}

Free trade in the Asia-Pacific region (AFTA) and Southeast Asia (MEA) becomes a challenge for family firms in developing their business activities. Strategies that can be taken by family firms to cope with existing market pressures can be pursued by implementing a diversification and compensation strategy. This study aims to explain and analyze the influence of diversification in related models, diversification on unrelated models, and executive compensation to firm value. In this study the population taken is a family firm in the manufacturing sector listed on the Indonesia

Corresponding Author:

Habiburrochman

habib@feb.unair.ac.id

Received: 10 February 2019

Accepted: 14 March 2019

Published: 28 March 2019

Publishing services provided by Knowledge E

(c) Habiburrochman et al. This article is distributed under the terms of the Creative Commons Attribution License, which permits unrestricted use and redistribution provided that the original author and source are credited.

Selection and Peer-review under the responsibility of the ICIEBP Conference Committee. Stock Exchange during the year 2012-2016 amounted to 140. The important finding of the research is that the diversification in the related model has no significant effect on firm value, the diversification on the unrelated model has no significant effect on firm value, the executive compensation in the related diversified company has a significant negative effect on firm value, then the executive compensation on the unrelated diversified company has a significant positive effect on the value of the company

Keywords: Related Diversification, Unrelated Diversification, Executive Compensation, Firm Value, Family Firm

\section{Introduction}

The family company is a form of company whose ownership structure with the composition of ownership contains family elements. A company can be interpreted as a family company if the founders and / or family members of the founder hold positions in top management, the board of directors, and have ownership of more than 5 percent (Chen et al. 2010: 42).

The existence of family elements in the company's ownership structure creates an agency conflict between the family ownership structure and the non-family ownership structure. The family ownership structure in the company is a majority ownership structure that can put pressure on management to provide more benefits to the family as 
shareholders. The pressure from family elements on the management of the company will give a loss to minority shareholders, where the interests of minority shareholders become more unnoticed.

Free trade in the Asia-Pacific (AFTA) and Southeast Asia (MEA) regions is a challenge for family companies in developing their business activities. The existence of free trade provides an opportunity for foreign companies to market their products in Indonesia, so that companies in Indonesia must have readiness in the competition. In addition, free trade in the Southeast Asia region provides opportunities for companies in Indonesia to increase capital for operational activities. This is because, free trade provides convenience for foreign investment into Indonesia, and provides convenience for companies to increase company's capital.

A family company is a company that seeks to carry out operational activities based on the financial capabilities they have. As a result of these conditions, family companies in Indonesia must be able to overcome all the limitations they have in order to improve their competitiveness and to increase the value of the company. Strategies that can be taken by family companies to meet these expectations, and face the existing market pressures can be pursued by implementing a diversification strategy.

Diversification strategy is a business development strategy through the expansion of business and geographical segments (Harto 2005). Diversification strategies are carried out by opening new business lines, expanding existing product lines, expanding product marketing areas, opening branch offices, conducting mergers, acquisitions and others (Harto 2005). Diversification strategy is chosen and applied by the company when the company is in certain conditions, namely when the company feels profit and company growth begins to decline in the initial industry of its business, besides diversification is also carried out in order to strengthen competitive advantage with competitors and in order to reduce investment risk because if the company only doing business in a single sector, the investment risk is quite large (Damciwar 1999). When diversifying, the company will become a multi-business company that does not only move on a single line of business, the more diverse business lines the company has, the more revenue sources that the company has.

This research emphasizes the form of strategies related to products created by the company. The company carries out two forms of product diversification, namely: related and unrelated diversification. Related diversification is a company effort to diversify business into another business that still has a close relationship with the previous business so that business strategies that are mutually compatible between each business can be developed (Hariadi, 2005). Unrelated diversification is an enterprise's efforts to diversify 
business into another business that does not have a close relationship with the previous business so that business strategies can be developed that are mutually compatible between each business. Diversified family companies believe that business diversity can increase company value. Firm value is a value formed by the company's internal resources and an increase in investor perceptions that are known through the company's stock price (Brigham and Houston 2003). stated that the company implemented a diversification strategy to improve the strategic competitiveness of its entire company. Diversification strategy is a way that companies do to improve strategic competitiveness, and increase the value of the company (Hitt et al. 2001: 253)

The research conducted (Park and Jang 2013) found empirical evidence that related diversifications have a positive impact on increasing corporate value. Park and Jang (2013) prove that related diversifications will provide benefits from the efficient use of production factors to produce products that have similarities to core products. The creation of related products accompanied by efficiency in the use of production factors will be useful in increasing company profits, so that the value of the company will increase.

The research conducted (Park and Jang 2013) contrasts with research conducted by (Hitt et al. 2001). (Hitt et al. 2001). found empirical evidence that related diversification does not affect the value of the company because the efficiency that occurs when the company conducts related diversification does not have a large enough influence to reduce operating expenses. This will have an impact that the company's profit performance will be more likely to remain and not experience a significant increase.

Companies that carry out unrelated diversification strategies have the aim of creating financial economies. The company does this by allocating capital to other companies that are not the same business. The company also conducts asset restructuring, namely buying other company's assets and then repairing and selling the assets at a price that exceeds the costs. In relation to company value, companies that do unrelated diversification can make new products that are different from the core business and can increase market power. With the existence of unrelated products, the core company has additional profit that directly contributes to total profit (Chen and Yu 2012).

Research conducted (Hyland 2013) found empirical evidence that unrelated diversifications have a positive impact on increasing firm value. (Hyland 2013) proves that unrelated diversifications will benefit from the expansion of market segmentation due to the increase in different products with the core product. Expansion of market segmentation will provide benefits for the company to increase sales volume so as to have an impact on improving the company's profit performance. The existence of a significant 
increase in profits will have a large influence on improving investor perceptions, so that the value of the company increases.

The research conducted (Hyland 2013) contrasts with research conducted by (Hitt et al. 2001). (Hitt et al. 2001) found empirical evidence that unrelated diversification had no effect on firm value because increased investment and expenses incurred to conduct unrelated diversification resulted in a decrease in the performance of profits generated by the company, so that unrelated diversification strategies did not become an attraction for investors.

In addition to implementing a diversification strategy, family companies also implement a policy in the form of compensation for management that aims to increase the value of the company. Compensation is income that can be in the form of money, direct goods, or indirectly received by management in return for services provided by the company (Yunita 2013). Compensation is a means of communication and performance evaluation for company management. With compensation, it is hoped that it can motivate directors to make the right decisions in increasing the value of the company.

The concept of agency theory according to (Jensen and Meckling 1976) describes a relationship that arises because of a contract between the principal and another party called the agent, where the principal delegates a work to the agent. Investors are principals in companies whose capital comes from investors' share ownership, while the management of the company is the agent. There are many mechanisms that can be pursued to reduce agency problems.

\section{Agency Problem}

The theory agency describes a relationship that arises because of a contract between the principal and another party called the agent, where the principal delegates a work to the agent (Jensen and Meckling 1976). Investors are principals in companies whose capital is derived from investor share ownership, while the management of the company is the agent (Jensen and Meckling 1976). In addition to the conflict between principal and agent, agency theory also defines the possibility of conflicts that occur between principals (Eisenhardt 1989). The conflict occurs between majority shareholders and minority shareholders. Company management will get more pressure from the majority shareholders to satisfy their interests. These conditions have an impact on the loss received by minority shareholders due to these conditions. 


\section{Diversification and Firm Value}

\subsection{Diversification influence on the related firm model on firm value}

Diversification in the related model is an enterprise's efforts to diversify business into another business that still has a close relationship with the previous business so that business strategies can be developed that are mutually compatible between each of these businesses (Hariadi 2005). Related diversification is diversified due to consumer considerations so that consumers are not saturated with one type of product. With the existence of new types of products, companies can explore economic scope (economies scope). This will make the value of the company better because it can reduce production costs and sell products at an existing competitive level, advantages that can not be done by companies with a single segment.

Based on the agency theory hypothesis there is agency conflict in question is the existence of conflict when the company is having a high free cash flow then the agents will direct it to investments that will increase company sales such as diversification even though the principals want dividend distribution from the free cash flow. This is because the evaluation of management performance is associated with the level of sales of the company. Chang and Wang (2007) succeeded in proving that there was an impact of product diversification strategies internationally with company performance. It was found that related diversification has a positive effect on performance.

H1a: Diversification in related models has a positive influence on firm value

\subsection{Diversification effect on unrelated models on firm values}

Diversification in an unrelated model is an enterprise's efforts to diversify business into another business that does not have a close relationship with the previous business so that a business strategy that is mutually compatible between each business can be developed (Hariadi 2005). Companies that do unrelated diversification are companies that are in a stable condition in the core business and its derivatives (related diversification). The company is expected to always increase the value of the company or improve its performance in a sustainable manner. Therefore, unrelated diversification becomes a way to improve its performance because the existence of unrelated diversification will increase market segmentation which will have an impact on increasing sales volume. The increase in sales volume from unrelated diversification activities will have an impact 
on increasing performance so that investor perception will increase from the unrelated diversification efforts.

Based on the agency theory hypothesis there is agency conflict in question is the existence of conflict when the company is having a high free cash flow then the agents will direct it to investments that will increase company sales such as diversification even though the principals want dividend distribution from the free cash flow. This is because the evaluation of management performance is associated with the level of sales of the company. Research conducted by Mackey (2006) stated that companies that do unrelated diversification benefit more from the diversification of the company. Based on the explanation, the proposed hypothesis is:

H1b: Diversification in unrelated models has a positive influence on firm value.

\subsection{Effect of executive compensation on firm values}

Compensation is a reward given by the company to the company manager. Rewards are given for the work performance carried out by managers to increase company wealth. The company manager seeks to achieve personal wealth by taking advantage of the opportunity to obtain compensation promised by the company. The opportunity is carried out by managers by utilizing the ability to practice financial report manipulation to show improvement in company performance. An increase in the performance of the company in accordance with what is expected by the owner of the company will give the impact of compensation received by the manager. This shows that there is motivation for management to get high compensation by improving the company's performance position. An increase in company performance will provide benefits for the company to increase the value of the company. The company considers compensation as a cost that must be suppressed so that the compensation provided is not in accordance with the executive needs / expectations. With a compensation system that is not in line with expectations and added to the basic human nature (moral hazard), the executive will try to find additional income in an incorrect way. This situation will encourage executives to maximize their personal interests.Based on agency theory, the compensation given to managers is a policy choice that allows to increase agency conflict. This is based on information held by managers greater than shareholders, so managers try to use the information for personal gain. Efforts to improve the performance of companies that will have an impact on increasing the value of the company is a way that is run by the company to get large compensation. Research conducted by Duffhues and Kabir 
(2008) found a negative relationship between executive compensation and company performance. Based on the explanation, the proposed hypothesis is:

$\mathrm{H}$ 2: Executive compensation has a negative influence on firm value

\section{Methodology}

\subsection{Research approach}

This research was conducted using a quantitative approach with explanatory research types. Quantitative approach is a structured research and quantifying data to be generalized (Anshori and Iswati 2009). Research according to this explanatory level aims to get an explanation of the relationship (causality) between variables through the hypothesis (Anshori and Iswati 2009).

\subsection{Variable operational definition}

\subsubsection{Company value (Dependent variables)}

The value of the company is the investor's perception of the whole of every equity owned by the company which is associated with the stock price. The price of the stock used generally refers to the closing price, and is the price that occurs when the stock is traded on the market (Lindenberg and Ross 1981). The value of the company in this study was measured using Tobin's $Q$ modification. Tobins' $Q$ can be calculated using the following formula:

$$
\mathrm{Q}=\frac{\mathrm{MVE}+\mathrm{D}}{\text { Total Aset }}
$$

\subsubsection{Diversification (Independent variables)}

Diversification strategies in companies are to diversify businesses related to core businesses (related) and businesses that are not associated with core (unrelated) businesses in order to obtain high profits from business segments owned (Hariadi 2005). Measurement of related diversification refers to measurements taken (Choe et al. 2014). The method of measurement is to use the following formula:

$$
R E L H S=\sum_{i=1}^{N} \frac{R E L}{4 N}\left[\frac{S j}{\sum_{i=1}^{N} S i}\right]^{2}
$$




\subsection{Executive compensation (Independent variables)}

One of the independent variables used in this study is executive compensation. Compensation is income that can be in the form of money, direct goods, or indirectly received by management in return for services provided by the company (Yunita 2013). Many ways to calculate how much compensation is obtained by the executive, one of them is by calculating how much cash compensation or shares received by the executive.

$$
\mathrm{KE}=\mathrm{Ln} \text { (Cash compensation }+ \text { Stock Compensation) }
$$

\subsection{Control variables}

\subsubsection{Company size}

The size of a company is the size of a company that can be seen through the company's ability to generate company revenue through the resources owned. The size of the company is one of the scales to classify companies. Company size is measured using the natural logarithm of the book value of the total assets of the company that refers to the study (Hanlon 2005).

$$
\text { Company Size }(\mathrm{l}, \mathrm{t})=\mathrm{Ln}(\text { Total Assets) }(\mathrm{i}, \mathrm{t})
$$

\subsubsection{Company age}

The age of the company can be interpreted to indicate the length of time the company runs a business since the company was founded. According to (George and Kabir 2012), the age of the company shows the maturity of each company in running a business. Age $(I, t)=$ the age of the company starts operating $(l, t)$

\subsubsection{Leverage}

Leverage is a ratio that shows the level of debt use to fund a company's assets. Leverage is proxied as the ratio between total debt to total assets of the company. The higher leverage will make managers careful in investing and will improve company performance (Park and Jang 2013). Leverage can be described in the following models:

$$
\text { Leverage }=\text { total debt/total assets }
$$




\subsubsection{Profitability}

Profitability is defined as the company's ability to generate profits from the sale of goods or services it produces (Astuti, 2004). This ratio is preferred by shareholders and company management as one of the tools for making investment decisions, whether this business investment will be developed, maintained and so on (Komalasari and Anna 2013). Profitability can be described in the following models:

Profitability $=($ operating income)/total sales

\subsubsection{Company growth}

The company's growth is one of the goals expected by internal and external parties of a company because it has an impact both for the company and investors, creditors and shareholders. The company's growth is the impact of the flow of corporate funds from operational changes caused by growth or decrease in business volume (Helfert 1996). In this study, the company's growth is calculated by the following formula (Akben Selçuk 2015):

$$
\text { Growth }=\text { (capital expenditures)/totalsales }
$$

\section{Population and Sample}

The population used is family companies in the manufacturing sector listed on the Indonesia Stock Exchange (IDX) for the period 2012-2016 which has been adjusted to the characteristics determined by the researcher and those needed in the research to answer the problem formulation and test the research hypothesis. The number of population in this study were 18 companies for each year, so that in this study conducted for five years, namely for the year 2012-3016, the total population was 90 companies.

In this study sampling was conducted using purposive sampling technique. According to (Anshori and Iswati 2009: 105) purposive sampling is a technique for determining samples by considering or based on certain criteria. so that the total research sample is equal to the total population of the study that is as many as 90 companies.

\subsection{Types and data sources}

The type of data used in this study is quantitative data. Quantitative data can be processed and analyzed using mathematical or statistical calculation techniques. Data 
sources used in the study are secondary data, namely: audited annual financial reports and annual reports obtained through the Indonesia Stock Exchange website (www.idx. co.id).

\subsection{Model and analysis techniques}

The analysis technique used in this study is multiple linear regression analysis. Multiple linear regression analysis in a study is used to measure the influence of more than one independent variable on one dependent variable. This research was conducted using two regression models, namely model 1 which was conducted to determine the effect of diversification on related models and executive compensation on firm value and model 2 which was conducted to determine the effect of diversification on unrelated models and executive compensation on firm value. This is because there are two research hypotheses that must be tested where each hypothesis examines the effect of one independent variable on one dependent variable.

Data analysis techniques were processed using Eviews 8 software. The analysis technique used in this study was descriptive statistical testing, classical assumption test that is normality test, and hypothesis test which consisted of coefficient of determination

\section{Data Analysis and Discussion}

\subsection{Descriptive statistics}

The total sample in this study for model 1 is 65 and for the model 2 is 25 family companies in the manufacturing sector. Descriptive statistics are statistics used to analyze data by describing or describing data that has been collected as it is without intending to make conclusions that apply to the public or generalization (Anshori and Iswati 2009: 116).

\subsection{Regression result (model 1)}

Based on the results in table 3 above, it indicates that the hypotheses one a and two $\left(\mathrm{H} 1 \mathrm{a}\right.$ and $\left.\mathrm{H}_{2}\right)$ in this study which state the Diversification Effect on the Related Model on Company Value is not proven and rejected, it is based on the calculated significance value (Sig) amounting to 0.3006 which is more than 0.1 (10\%). For executive compensation of firm value has a negative effect and proven significant, then it was accepted because the significant value of the calculation was 0.0862 which was $>0.1$. 
TABLE 1: Decriptive Statistic Model 1.

\begin{tabular}{l|c|c|c|c|c|}
$\begin{array}{l}\text { Variabel } \\
\text { Nilai }\end{array}$ & Mean & SD & Max & Median & Min \\
\hline $\begin{array}{l}\text { Tobins'q } \\
\text { Diversifikasi }\end{array}$ & 1.107863 & 1.080310 & 4.564435 & 1.505407 & 0.090918 \\
\hline RELHS & 0.099506 & 0.344282 & 0.971835 & 0.292620 & 3.54 E-06 \\
\hline compensation & & & & & \\
\hline COMP & 23.15666 & 1.389401 & 27.45577 & 23.42661 & 21.19826 \\
\hline Control Variable & & & & & \\
\hline SIZE & 28.23000 & 1.495749 & 32.15100 & 28.60851 & 26.79500 \\
\hline AGE & 43.00000 & 7.543145 & 58.00000 & 41.76923 & 22.00000 \\
\hline LEV & 0.477241 & 0.185323 & 0.837462 & 0.471518 & 0.165185 \\
\hline ROA & 0.075329 & 0.077358 & 0.442000 & 0.092737 & -0.02264 \\
\hline GROWTH & 0.041140 & 0.042337 & 0.147797 & 0.054741 & -0.026000 \\
\hline
\end{tabular}

TABLE 2: Decriptive Statistic Model 2.

\begin{tabular}{l|c|c|c|c|c|}
$\begin{array}{l}\text { Variable } \\
\text { Value }\end{array}$ & Mean & SD & Max & Median & Min \\
\hline $\begin{array}{l}\text { Tobins'q } \\
\text { Diversification }\end{array}$ & 1.535019 & 1.439989 & 5.509047 & 1.988768 & 0.284858 \\
\hline RELHS & 0.276406 & 0.217849 & 0.711383 & 0.297703 & 0.001747 \\
\hline compensation & & & & & \\
\hline COMP & 22.18188 & 1.992476 & 26.30200 & 23.29301 & 21.04947 \\
\hline Control Variable & & & & & \\
\hline SIZE & 29.07100 & 1.472702 & 30.83700 & 28.75689 & 26.33600 \\
\hline AGE & 37.00000 & 7.977468 & 44.00000 & 34.84000 & 25.00000 \\
\hline LEV & 0.540000 & 0.188062 & 0.850000 & 0.515862 & 0.140000 \\
\hline ROA & 0.115500 & 0.102819 & 0.289100 & 0.090319 & -0.26860 \\
\hline GROWTH & 0.045800 & 0.316701 & 1.571800 & 0.140924 & 0.009200 \\
\hline
\end{tabular}

Based on the data in table 3 above, a simple linear regression equation will be obtained as follows:

$$
\begin{aligned}
& \text { TOBINS }=-1.865772-0.419631 \text { RELHS }-0.244600 \text { COMP }+0.289470 \text { SIZE } \\
& +0.016510 \text { AGE }-0.863132 \text { LEV }+7.317061 \text { ROA }-0.335632 \text { GROWTH }+\mathrm{e}
\end{aligned}
$$

Based on the results in table 4 above, indicating that the hypothesis one $b$ and two $\left(\mathrm{H} 1 \mathrm{~b}\right.$ and $\left.\mathrm{H}_{2}\right)$ in this study which states the effect of Diversification on Unrelated Models 
TABLE 3: Results of Model 1 Multiple Linear Regression Analysis.

\begin{tabular}{|c|c|c|c|c|}
\hline Variable & Coefficient & Std. Error & t-Statistic & Prob. \\
\hline RELHS & -0.419631 & 0.401715 & -1.044597 & 0.3006 \\
\hline COMP & -0.2446 & 0.140071 & -1.746262 & 0.0862 \\
\hline SIZE & 0.28947 & 0.123472 & 2.344414 & 0.0226 \\
\hline AGE & 0.01651 & 0.018115 & 0.911437 & 0.3659 \\
\hline LEV & -0.863132 & 0.704278 & -1.225556 & 0.2254 \\
\hline ROA & 7.317061 & 1.490533 & 4.909022 & 0 \\
\hline GROWTH & -0.335632 & 2.506812 & -0.133888 & 0.894 \\
\hline C & -1.865772 & 2.492222 & -0.748638 & 0.4572 \\
\hline \multicolumn{5}{|l|}{ Information: } \\
\hline
\end{tabular}

TABLE 4: Results of Model 2 Multiple Linear Regression Analysis.

\begin{tabular}{|c|c|c|c|c|}
\hline Variable & Coefficient & Std. Error & t-Statistic & Prob. \\
\hline RELHS & -1.351017 & 1.480591 & -0.912484 & 0.3743 \\
\hline COMP & 0.609786 & 0.166318 & 3.666390 & 0.0019 \\
\hline SIZE & -0.055357 & 0.284875 & -0.194319 & 0.8482 \\
\hline AGE & 0.038913 & 0.037732 & 1.031292 & 0.3169 \\
\hline LEV & -0.586598 & 1.947149 & -0.301260 & 0.7669 \\
\hline ROA & -2.386455 & 2.501833 & -0.953883 & 0.3535 \\
\hline GROWTH & -0.622892 & 0.871003 & -0.715144 & 0.4842 \\
\hline C & -10.97068 & 5.539760 & -1.980353 & 0.0641 \\
\hline \multicolumn{5}{|c|}{ Information: } \\
\hline
\end{tabular}

on Company Value is not proven and rejected, it is based on the significance value of the calculation (Sig) amounting to 0.3743 which is more than 0.1 (10\%). For executive compensation on firm value has a positive and significant effect, it is said to be rejected because the significant value of the calculation is $0.019>0.1$.

Based on the data in table 4 above, a simple linear regression equation will be obtained as follows:

$$
\begin{aligned}
& \text { TOBINS }=-10.97068-1.351017 \text { RELHS }+0.609786 \text { COMP }-0.055357 \text { SIZE + } \\
& 0.038913 \text { AGE }-0.586598 \text { LEV }-2,386455 \text { ROA }-0.622892 \text { GROWTH }+\mathrm{e}
\end{aligned}
$$




\subsection{Diversification effect on models related to firm value}

Hypothesis 1a stated that diversification in related models does not have a significant effect on firm value. The results showed that family companies that were able to develop similar products with core products were not able to give a strong influence on the decisions of capital market investors to invest their funds. Capital market investors have a perception that companies that diversify on related models will not provide a significant increase in the sales volume of their new products. This is because new products that are created will not be different from existing products, so fulfillment of consumer preferences for unique new products is not fulfilled. This will have an impact on the absence of more profits for capital market investors from the efforts of family companies to conduct related diversification. In addition, the addition of subsidiaries and the addition of new assets for family companies that diversify in related models do not influence the market perception of investors. capital. Capital market investors have the view that family companies that make additional subsidiaries and new assets do not provide more profits for the company so that they do not have an impact on capital market investors.

Based on agency theory, family companies are companies that experience negative perceptions from stakeholders on the operationalization of the company. This perception is formed due to the efforts of family companies to give excessive benefits to family members who have share ownership in the company. To minimize these negative perceptions, family companies will publish efforts to diversify their products as information to stakeholders so that information bias can be minimized. However, information on diversification in similar products carried out by family companies lacks good response from capital market investors due to a perception of the company's inability to develop competitive advantage.

The results of this study are in line with research conducted by (Hitt et al. 2001) which found empirical evidence that related diversification does not affect the value of the firm.

\subsection{Effects of diversification on unrelated models on firm values}

Hypothesis $1 \mathrm{~b}$ stated that diversification in unrelated models has no significant effect on firm value. The results show that diversification in unrelated models by creating new subsidiaries that are different from the parent, as well as diversification in the formation of new assets will give negative appreciation from capital market investors. The efforts 
of family companies to create new subsidiaries that are different from the parent and the effort to invest in new assets will require substantial funding. The funding will be obtained by the company through retained earnings held by the family company and the profits generated by the company. These conditions lead to a loss of opportunity for capital market investors to gain more profits from the profits generated by companies owned by family elements. This will encourage capital market investors to withdraw their investment funds to family companies that invest heavily in the formation of new subsidiaries and create new assets.

Based on agency theory, family companies are companies that experience negative perceptions from stakeholders on the operationalization of the company. This perception is formed due to the efforts of family companies to give excessive benefits to family members who have share ownership in the company. To minimize these negative perceptions, family companies will publish efforts to diversify their products as information to stakeholders so that information bias can be minimized.

The results of research conducted by (Tantra and Ida Ayu 2017) stated that companies that implement unrelated diversification strategies have no influence on the value of the firm.

\subsection{Effect of executive compensation on firm values}

Hypothesis 2 stated that compensation affects the value of the company. The results showed that executive compensation in diversified companies that have related diversification had a negative effect and proved to be significant to the value of the company, while executive compensation in diversified companies that carried out unrelated diversification had a positive effect and proved to be significant to the value of the company.

The results showed that the compensation given to managers in family companies that do related diversification is an effort of the shareholders of family elements as an effort to perpetuate the desire for family ownership in the company to get the maximum profit from the operation of the company. Family elements in company ownership will encourage managers to carry out certain opportunistic behaviors so that shareholder profits can increase. As a result of these efforts, the shareholders of the family element will give the manager benefits in the form of compensation or incentives. The manager's efforts to meet the expectations of shareholders from family elements by carrying out opportunistic actions will lead to negative perceptions of capital market investors. This is due to fraudulent efforts made by companies that will have an impact on the 
sustainability of the company in the future, so that it can cause losses to capital market investors.

The results of the study prove that compensation given to managers of family companies that conduct unrelated diversification is an effort from shareholders to give appreciation for the manager's efforts to improve the company's performance through product development efforts. The existence of these efforts will provide a positive perception of the amount of effort that will be carried out by managers in an effort to improve their performance so that an increase in company performance can occur annually. The increase in performance will encourage capital market investors to make efforts to increase investment in family companies that do unrelated diversification and are able to provide substantial compensation to managers.

Based on agency theory, compensation is an attempt to motivate managers to improve their performance properly, and avoid opportunistic behavior. The existence of information related to compensation provided by companies in the financial statements is an attempt to minimize the information gap between the principal and agent, and the majority shareholders with minority shareholders. The compensation information presented by family companies that carry out related diversification will have an impact on the high negative perception of investors as minority shareholders, so that the value of the company will decrease, while the compensation information presented by family companies that run unrelated diversification will impact the high positive perception of investors as minority shareholders.

Research conducted by (Duffhues and Kabir 2008) found a negative relationship between executive compensation and company value. But the results of this study contradict the research conducted by (Indreswari 2013) saying that compensation has a positive effect and is proven to be significant to the value of the firm.

\section{Conclusion}

Based on the results of the discussion of the research described previously, it can be concluded as follows:

1. The results of testing and analysis show that related diversification has a negative effect and does not prove significant to the value of the company. This finding supports the research (Hitt et al. 2001) which finds empirical evidence that related diversification does not affect the value of the company. 
2. The results of testing and analysis show that unrelated diversification does not have a significant effect on the value of the company. This finding is in line with the results of the study (Tantra and Ida Ayu 2017).

3. The results of testing and analysis show that executive compensation affects the value of the company. The results of this study are in line with (Indreswari 2013) and (Duffhues and Kabir 2008)

\section{Suggestion}

Suggestions that need to be considered due to limitations in the study are the scope of research only on family companies in the manufacturing sector, so that the results of this study cannot be generalized to other sectors. Therefore, in subsequent studies can use family companies from the non-manufacturing sector to provide a more comprehensive picture related to the influence of related and unrelated diversification and executive compensation on company value.

\section{References}

[1] Akben Selçuk, Elif. (2015). Corporate diversification and firm value: evidence from emerging markets. International Journal of Emerging Markets, 10(3), 294-310.

[2] Anshori, Muslich, dan Sri Iswati. (2009). Metodologi penelitian kuantitatif. Surabaya: Pusat Penerbitan dan Percetakan UNAIR.

[3] Astuti, Dewi. (2004). Manajemen keuangan perusahaan. Jakarta: Ghalia Indonesia.

[4] Bonner, Sarah E, dan Geoffrey B Sprinkle. (2002). The effects of monetary incentives on effort and task performance: theories, evidence, and a framework for research. Accounting, Organizations and Society, 27(4), 303-345.

[5] Chang, Shao-Chi, dan Chi-Feng Wang. (2007). The effect of product diversification strategies on the relationship between international diversification and firm performance. Journal of world business, 42(1), 61-79.

[6] Choe, Chongwoo, Tania Dey, dan Vinod Mishra. (2014). Corporate diversification, executive compensation and firm value: Evidence from Australia. Australian Journal of Management, 39(3), 395-414.

[7] Damciwar, Averus. (1999). Strategi Diversifikasi usaha Perusahaan Jasa Konstruksi (Studi kasus Pada PT X). 
[8] Duffhues, Pieter, dan Rezaul Kabir. (2008). Is the pay-performance relationship always positive?: Evidence from the Netherlands. Journal of multinational financial management, 18(1), 45-60.

[9] Eisenhardt, Kathleen M. (1989). Agency theory: An assessment and review. Academy of management review, 14(1), 57-74.

[10] Hanlon, Michelle. (2005). The persistence and pricing of earnings, accruals, and cash flows when firms have large book-tax differences. The accounting review, 80(1), 137-166.

[11] Harto, Puji. (2005). Kebijakan Diversifikasi Perusahaan dan Pengaruhnya Terhadap Kinerja: Studi Empiris Pada Perusahaan Publik di Indonesiia. Simposium Nasional Akuntansi VIII.

[12] Helfert, Erich A. (1996). Teknik Analisis Keuangan: Petunjuk Praktis untuk Mengelola dan Mengukur Kinerja Perusahaan. Jakarta: Erlangga.

[13] Hitt, Michael A, Leonard Bierman, Katsuhiko Shimizu, dan Rahul Kochhar. (2001). Direct and moderating effects of human capital on strategy and performance in professional service firms: A resource-based perspective. Academy of Management journal, 44(1), 13-28.

[14] INDRESWARI DYAH RETNO, DYAH. (2013). PENGARUH BOARD DIVERSITY DAN KOMPENSASI DEWAN DIREKSI TERHADAP NILAI PERUSAHAAN (STUDI EMPIRIS PADA PERUSAHAAN MANUFAKTUR YANG TERDAFTAR DI BEI TAHUN 2010). Fakultas Ekonomi.

[15] Jensen, Michael C, dan William H Meckling. (1976). Theory of the firm: Managerial behavior, agency costs and ownership structure. Journal of Financial Economics, 3(4), 305-360.

[16] Komalasari, Desi, dan Yane Dewi Anna. (2013). Pengaruh Mekanisme Corporate Governance Ukuran Perusahaan Dan Profitabilitas Perusahaan Terhadap Pengungkapan Corporate Sosial Responsibility Pada Industri Perbankan yang Listing di BEl Periode 2008-2011. Jurnal Akuntansi.

[17] Mackey, Tyson B. (2006). Essays on corporate diversification and firm value. The Ohio State University.

[18] Park, Kwangmin, dan SooCheong Shawn Jang. (2013). Capital structure, free cash flow, diversification and firm performance: A holistic analysis. International Journal of Hospitality Management, 33, 51-63.

[19] Yunita, Sari. (2013). Pengaruh Gaya Kepemimpinan, Motivasi, Disiplin Kerja Terhadap Kinerja Pegawai di Kantor Pelayanan Kekayaan Negara dan Lelang Medan. UNIMED. 